\title{
ACRL honors the 2014 award winners, part 1 A recognition of professional development
}

\section{Kenney wins Hugh C. Atkinson Memorial award}

Anne R. Kenney, Carl A. Kroch University librarian at Cornell University, has been named the winner of the Hugh C. Atkinson Memorial Award. Kenney will receive a cash award and citation during the ALA Annual

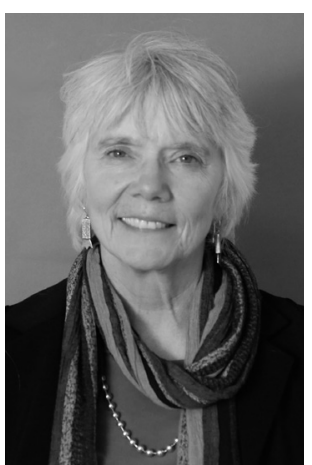

Anne R. Kenney Photograph by William Staffeld/Cornell AAP
Conference in Las Vegas.

Named in honor of one of the pioneers of library automation, the Atkinson Award recognizes an academic librarian who has made significant contributions in the area of library automation or management, and has made notable improvements in library services or research.

"The nomination for Anne R. Kenney presented the committee with an extraordinary tour of innovative achievements and service to the profession," said Lisa Carlucci Thomas, Hugh C. Atkinson Memorial Award committee chair and director at Design Think Do. "Anne's leadership on significant projects, such as 2CUL, arXiv, Project Euclid, and Making of America; her influential work on large-scale digitization and digital preservation standards; and her global contributions in Myanmar, Cuba, China, and beyond demonstrates her outstanding creativity, agility, risk-taking, and collaborative spirit.
"Anne's peers describe her as a 'fearless visionary,' 'a thoughtful, intellectual leader,' and a 'digital library pioneer;' noting that 'Hugh Atkinson himself would be proud' to call her a colleague," continued Thomas. "Several colleagues who knew Hugh Atkinson shared examples of how 'Anne Kenney brings Hugh's spirit of technology-harnessing, tradition-busting leadership-with an additional dash of adventure as well.' She inspires and generates enthusiasm for new programs and strategies and thrives to bring individuals together around a shared purpose."

The Hugh C. Atkinson Award is jointly sponsored by four divisions of ALA: ACRL, Association for Library Collections and Technical Services, Library Leadership and Management Association, and Library and Information Technology Association. The award is funded from an endowment established to honor Hugh C. Atkinson.

Donations to the endowment may be sent to Chase Ollis, ACRL, 50 East Huron St., Chicago, Ill. 60611.

\section{Excellence in Academic Libraries Award winners}

The Excellence in Academic Libraries Award winners are Illinois Central College (ICC) Library, East Peoria, Illinois; Lafayette College Skillman Library, Easton, Pennsylvania;

Chase Ollis is ACRL program coordinator, e-mail:collis@ ala.org

(c) 2014 Chase Ollis 


\section{Bucknall named Academic/Research Librarian of the Year}

Tim Bucknall, assistant dean of libraries and head of electronic resources and information technologies at the University of North Carolina -Greensboro (UNCG), is the 2014 ACRL Academic/Research Librarian of the Year.The award, sponsored by YBP Library Services, recognizes an outstanding member of the library profession who has made a significant national or international contribution to academic/research librarianship and library development.

Bucknall will receive a \$5,000 award during the ACRL President's Program at the 2014 ALA Annual Conference in Las Vegas.

"Tim Bucknall's service to the library profession is truly impressive," noted Laurel Littrell, chair of the ACRLAcademic/Research Librarian of the Year Award Committee and director of library planning and assessment at Kansas State University.

"Among his many accomplishments, he founded the Carolina Consortium in 2004, to provide

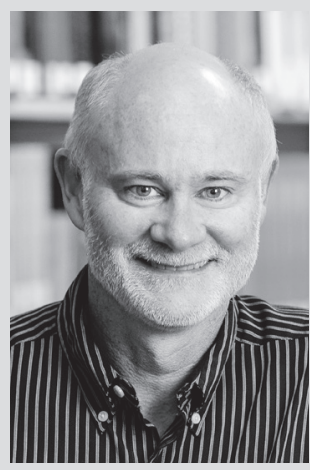

Tim Bucknall
"Tim's work in building consortia, leveraging e-resources, and improving use of information technology are important contributions to the profession," added ACRL Executive Director Mary Ellen Davis. "I am delighted at his inclusive approach and the value that he places on teamwork and collaboration, traits that are firmly engrained in the ACRL culture."

Bucknall's creative, team-driven approach to librarianship; coalition-building abilities, especially between the library and conveyor communities; and innovative approach have earned him the respect, trust, and admiration of his colleagues in the Carolinas and beyond.

Bucknall has discussed his work at a wide range of conferences, including the Charleston Conference, Association of Southeastern Research Libraries conferences, Electronic Resources and Libraries, the North American Serials Interest Group conference, Computers in Libraries,ACRL conferences, and the ALA Annual Conference.

His publications include Library Technology and User Services:Planning, Integration, and Usability Engineering (with Anthony Chow, 2012), "Usability Engineering and Technology Integration in Libraries" in The International Journal of Science in Society (with Anthony Chow, 2009), "A Comparative Evaluation of Journal Literature Access Options at the University of North Carolina at Greensboro" in Interlending and Document Supply (2009), and "U-Search:A User Study of the CDROM Service at the University of North Carolina at Chapel Hill" in $R Q$ (with Rikki Mangrum, 1998).

Prior to joining UNCG as head of the Electronic Resources and Information Technology Department in 1994, Bucknall served as electronic services librarian at the University of North CarolinaChapel Hill from 1989 to 1994 . He received the North Carolina Library Association RTSS Significant Achievement Award in 2001 and was named a 2006 Mover and Shaker by Library Journal. 
and California Polytechnic State University's Robert E. Kennedy Library, San Luis Obispo, California. Sponsored by ACRL and YBP Library Services, the award recognizes the staff of a college, university, and community

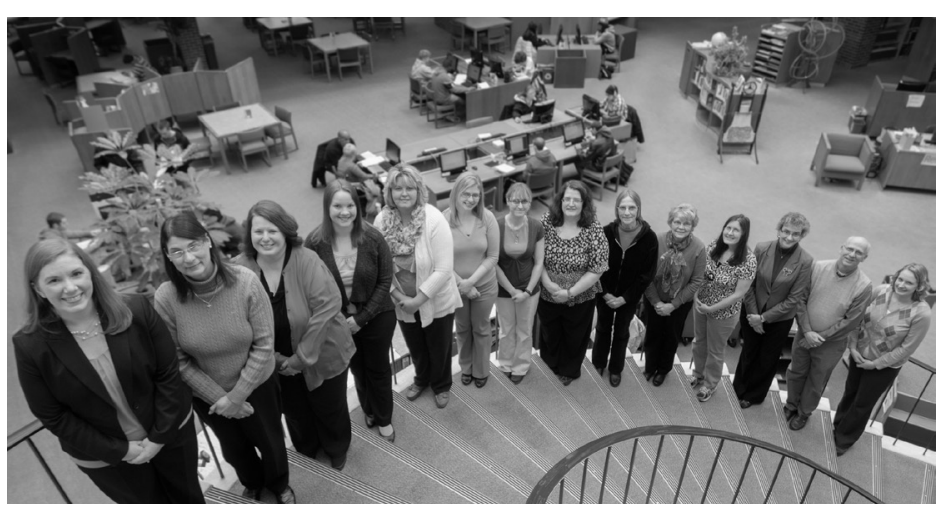

Staff at Illinois Central College Library. to raise the students' odds of success by getting them to read," said Joyce Ogburn, chair of the 2014 Excellence in Academic Libraries Committee and dean of the libraries at Appalachian State University. "The library also believes in staff development and supports a robust Library Tech training program in the evening and encourages participation in leadership training on campus. They exercise extensive outreach to the campus community and outcomes are demonstrated that go beyond the library. The application was

college library for programs that deliver exemplary services and resources to further the educational mission of the institution.

"These deserving recipients demonstrate the commitment to student learning, campus outreach, and digital scholarship, with a focus on continuous innovation and integration with the campus community that exemplify today's best academic and research libraries," said ACRL Executive Director Mary Ellen K. Davis. "Receiving an Excellence in Academic Libraries Award is a national tribute to each library and its staff for outstanding services, programs and leadership."

ICC Library, winner in the community college category, was chosen for its emphasis on disadvantaged students and staff development.

"Illinois Central is being recognized for an emphasis on students who are disadvantaged and not strong readers, finding approaches enhanced by telling stories of what happens throughout the day in the life of the library and the users."

"We feel so honored and humbled to receive this award," said ICC library director Cate Kaufman. "The ICC's entire library staff has collaborated in recent years to re-think the delivery of services and the availability of resources we provide our students and

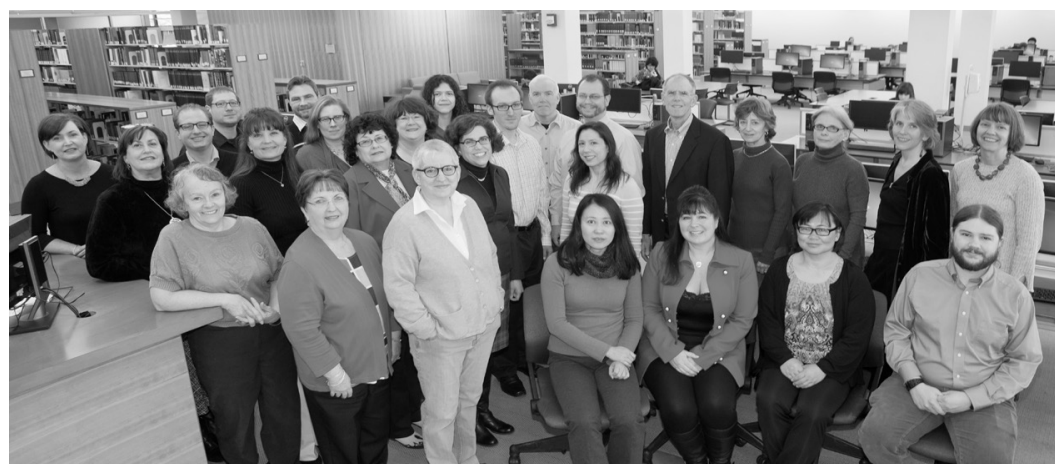

Staff at Skillman Library of Lafayette College.

the college as a whole. The award reaffirms the importance of those efforts and encourages us to continue to adapt and meet the demands of the ever-changing climate of higher education."

Skillman Library of Lafayette College, winner of this year's award in the college category, impressed the selection committee 
with its digital scholarship experimentation, as well as its pioneering in acquisition models.

"Lafayette College seeks to be a model for other colleges and has been in the forefront on getting grants and experimenting with digital scholarship in the liberal arts setting," noted Ogburn. "The library implemented new models of acquisitions for journals by combining strategic cancellations with articleby-article purchase. They led the way for other liberal arts colleges by developing consortial approaches to patron-driven acquisitions for e-books, joining $\mathrm{Ha}-$ thi Trust, and implementing the Ithaka faculty survey on their campus."

"We are greatly honored to be selected by our peers to receive this award, which recognizes not only our library's innovative work on behalf of Lafayette College but also our strategic collaboration with other col-

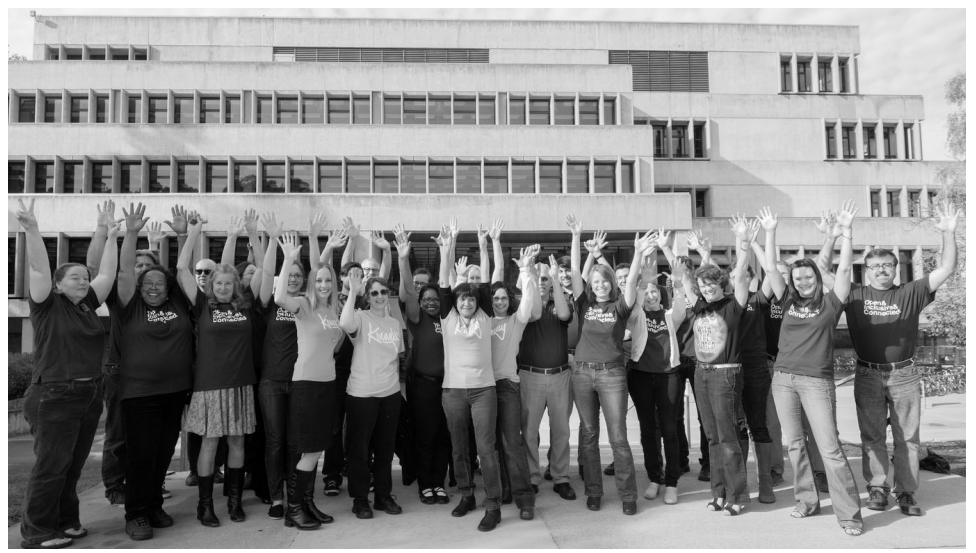

Staff of the California Polytechnic State University's Robert E. Kennedy Library. level of student engagement and partnerships across campus. We were taken by the LibRATs program, or Library Research Assistance Technicians, where highly trained students provide instruction and help other students with research. Among their other innovations are developing a Data Studio to address data literacy and instigating access to and development of open access textbooks to decrease costs for students."

"It is a true honor to be chosen for this year's ACRL Excellence Award," said Anna K. leges and universi-

ties," said Neil J. McElroy, library director at Lafayette College.

"While the award nomination highlights our programmatic initiatives and technological innovations, we are mindful that our success has been enabled by those relationships of trust and reciprocity that we've been privileged to build with the Lafayette community and colleagues at other institutions over many years. We are deeply pleased and grateful."

The Robert E. Kennedy Library at Cal Poly State University, winner in the university category, was selected for its innovations in student engagement.

"Cal Poly State University library uses a thematic approach in their application, documenting their emphasis on being open, inclusive, and connected," said Ogburn.

"Their ideas are fresh and appealing across the three areas. The committee noted the
Gold, university librarian at California Polytechnic State University. "The Robert E. Kennedy Library's 'open, inclusive, connected' culture reflects the strengths of California Polytechnic State University's cross-disciplinary excellence. Every person at the Kennedy library works hard to amplify those strengths, through our partnerships with students, staff, and faculty. Many academic libraries are emerging as dynamic campus centers for learning and research, and we are thrilled to be recognized among them this year by our peers, and by this award."

"All three achieved excellence without the benefit of a new or greatly renovated library," noted Ogburn. "Each made the most of the resources at hand and capitalized on their staffs' energies and talents to blaze new territory or to serve their users in new ways." 
Each winning library will receive $\$ 3,000$ and a plaque, to be presented at an award ceremony held on each recipient's campus.

\section{Grassian wins IS Miriam Dudley Instruction Librarian Award}

Esther Stampfer Grassian, distinguished librarian (UCLA), emerita, is the winner of

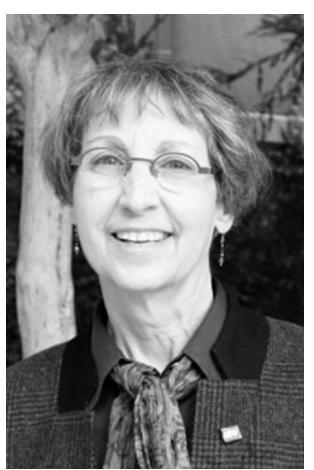

Esther Stampfer Grassian ACRL's Instruction Section's (IS) Miriam Dudley Instruction Librarian Award. The award honors Miriam Dudley, whose efforts in the field of information literacy led to the formation of IS. The honor recognizes a librarian who has made a significant contribution to the advancement of instruction in a college or research library environment.

Grassian will receive a $\$ 1,000$ award, along with a plaque

"Esther Grassian's deep impact on the field of information literacy has been sustained over the length of her distinguished career, including 41 years as a librarian in the UCLA College Library," said IS Miriam Dudley Award Chair Susan Miller, visiting librarian at Illinois Wesleyan University. "Grassian's contributions span all areas of librarianship; she is nationally recognized for her leadership, teaching, writing, and presenting in the area of information literacy instruction and advocacy.

"Grassian's extensive service to the profession ranges from local to international in scope, and includes work with the California Clearinghouse on Library Instruction, ALA, ACRL, the Instruction Section, LIRT, REFORMA, and the European Conference on Information Literacy," noted Miller. "The Instruction Section is pleased to honor Esther Grassian, who has made an especially significant contribution to the advancement of instruction in academic libraries."

\section{Farkas, Hofer, Molinelli, and Willson- \\ St. Clair receive IS Innovation Award}

Meredith Farkas, Amy Hofer, Lisa Molinelli, and Kimberly Willson-St. Clair, all of Portland

State University, have been selected to receive ACRL's Instruction Section (IS) Innovation award for their work on the software, Library DIY, which assists students in finding the information they need quickly. Farkas is

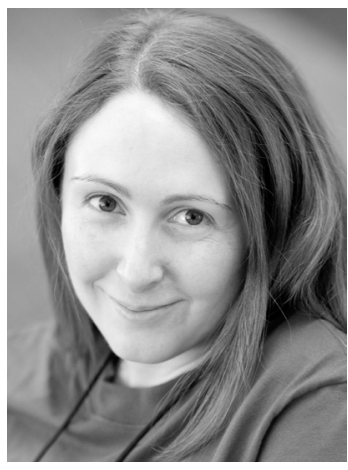

Meredith Farkas the general education instruction coordinator, Hofer is the distance learning librarian, and Molinelli and Wilson-St. Clair are reference and instruction librarians. All four primarily work to develop creative and sustainable instructional services to support students.

Sponsored by ProQuest, the annual award recognizes a project that demonstrates

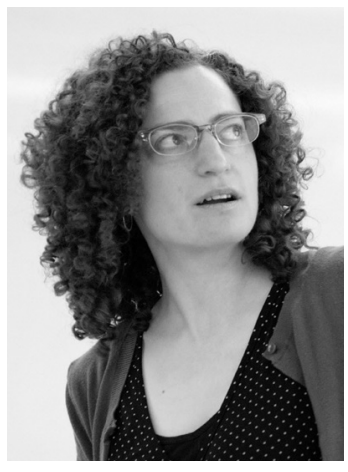

Amy Hofer creative, innovative, or unique approaches to information literacy instruction or programming

A prize of $\$ 3,000$ and a plaque will be presented to the group.

"The committee liked the DIY approach and was impressed by the scope of the project and ease of use," said award committee cochairs Lori Dubois of Williams

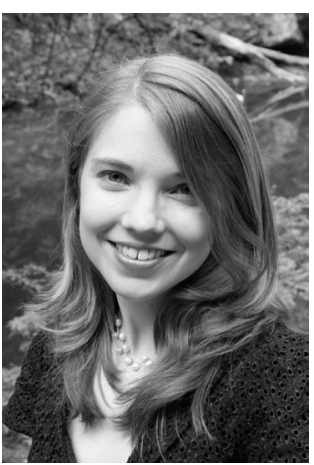

Lisa Molinelli 


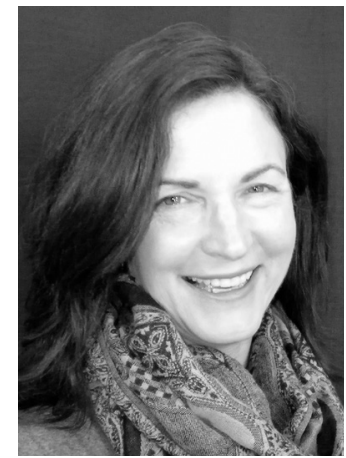

College and Susanna Eng-Ziskin of California State UniversityNorthridge. "While many libraries have comprehensive information literacy tutorials, this project provides a model for Kimberly Willson-St. Clair libraries considering how to help students quickly answer questions as they are doing their research."

Library DIY is a system of learning objects at Portland State University that is designed to give students the quick answers they need for point-of-need support. The content and information architecture of Library DIY is designed to mirror a reference desk transaction; students can drill down to the specific piece of information they need rather than having to skim through a long tutorial to find what they're looking for.

\section{Holliday and Rogers win IS Ilene F. Rockman Publication of the Year Award}

Wendy Holliday, head of academic programs and course support at Northern

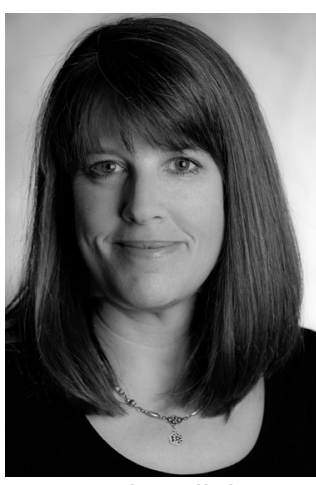

Wendy Holliday
Arizona University, and Jim Rogers, associate professor and director of the Intensive English Language Institute at Utah State University, have been chosen as the winners of ACRL's Instruction Section (IS) Ilene F. Rockman Publication of the Year Award, for their article, "Talking About Information Literacy: The Mediating Role of Discourse in a College Writing Classroom," published in 2013 by portal: Libraries and the Academy.
The award recognizes an outstanding publication related to library instruction published in the past two years.

The award, donated by Emerald Group Publishing Ltd., consists of a plaque and a cash prize of $\$ 3,000$.

"Holliday and Rogers's study is important because it challenges us to think about how the words we use to describe the research process in the classroom affects student learning and engagement in research," said award committee cochairs Lori DuBois of Williams College and Susanna Eng-Ziskin of California State University-Northridge.

In their study, Holliday and Rogers analyze how librarians and writing instructors' word choices focusing on "sources" as containers instead of the ideas within them

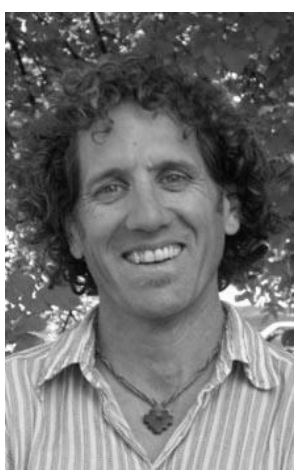

Jim Rogers may lead students to focus on finding sources to fulfill the assignment parameters rather than engaging more fully with the information to learn about the research topic.

Holliday has been an academic librarian since 2002, with an emphasis on information literacy and teaching and learning.

Rogers has extensive experience teaching English as a Second Language (ESL) and teaching graduate students in ESL education programs, as well as in creating faculty professional development programs related to ESL and teaching and learning.

\section{Micham wins WGSS Career Achievement Award}

Laura Micham, Merle Hoffmann director of the Sallie Bingham Center for Women's History and Culture and curator of gender and sexuality history collections in the David M. Rubenstein Rare Books and Manuscripts Library at Duke University, has been selected as the winner of ACRL's Women and Gender 
Studies Section (WGSS) Career Achievement Award. The award honors significant longstanding contributions to women's studies in the field of librarianship over the course of a career.

"The awards committee selected Laura Micham based on her significant leadership strengths and contributions to the world of archives as the Merle Hoffman Director of the Sallie Bingham Center for Women's History and Culture at Duke University," said

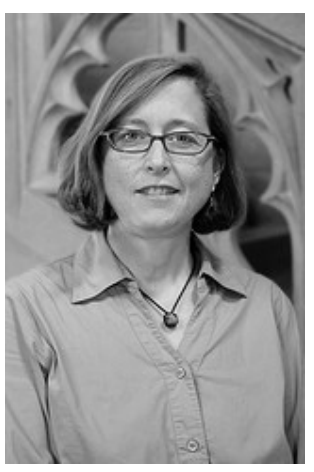

Laura Micham award chair Jennifer Mayer, associate librarian at the University of Wyoming. "One colleague describes her vision and commitment as bringing the dreams of 'a vibrant hub of feminist scholarship' to its current reality. Another describes her 'unparalleled intellectual grasp of the field of women and gender studies, her boundless energy for programming, and her remarkable ability to work with all sectors of the university community.'"

"The committee looked at Micham's tenure as director and the resulting successful archival programs, instructional offerings and collections in women and gender studies disciplines-all of exemplary quality-developed under her leadership. The committee was also impressed with her proactive work with students-how she makes collections come alive for students, and her passion to connect students with archival resources.

"During her directorship, the Sallie Bingham Center has grown both its collections and its national profile. Micham is described as an individual who fights hard and fairly-and successfully-for archives. Her work and partnerships with other Duke curators have led to the acquisitions of highprofile collections, including the Dorothy Allison papers, the Meredith Tax papers, the records of Ipas, and many other significant collections."

A plaque will be presented to Micham.

\section{Accardi wins WGSS Significant Achievement Award}

Maria T. Accardi, coordinator of library instruction at Indiana University Southeast, is the winner of ACRL's Women and Gender Studies Section (WGSS) Award for Significant Achievement in Woman's Studies Librarianship. The WGSS award honors a significant or one-time contribution to women's studies librarianship.

"The committee selected Maria T. Accardi based on her noteworthy ac-

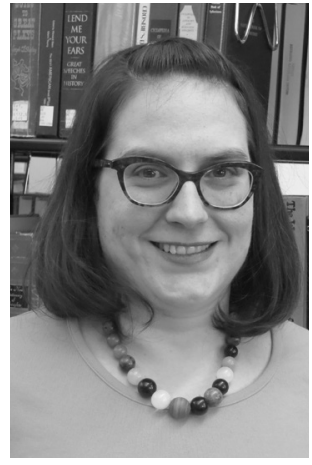

Maria T. Accardi complishment, the 2013 book Feminist Pedagogy for Library Instruction, published by Library Juice Press," said award chair Jennifer Mayer, associate librarian at the University of Wyoming. "The committee was impressed by her book-length treatment of the intersection of information literacy and feminist theory, which is unique, important, and fills a gap in the literature."

While theoretical, the book is also an accessible, practical handbook including exercises and assessment strategies," noted Mayer.

“Accardi's work also helps readers apply and integrate feminist pedagogical approaches in less-likely places-across the curriculum, in online classes, and with students who may not identify with feminism or understand the relevance in their lives. Committee members valued the wide appeal of Accardi's book. Feminist Pedagogy for Library Instruction is a must-read for any librarian with interests in feminist issues, pedagogy, and library instruction."

A plaque will be presented to Accardi. $\boldsymbol{n}$ 